\title{
Clinicopathological Behavior and Treatment- related Outcome of Rare Salivary Duct Carcinoma: The Shaukat Khanum Memorial Cancer Hospital Experience
}

Abdul Wahid Anwer ${ }^{1}$, Muhammad Faisal ${ }^{2}$, Mohammad Adeel ${ }^{3}$, Omer Waqas ${ }^{4}$, Muhammad Abu Bakar ${ }^{5}$, Saman Qadeer $^{6}$, Maliha Koukab ${ }^{2}$, Raza Hussain ${ }^{2}$, Arif Jamshed ${ }^{7}$

1. Department of Surgical Oncology, Shaukat Khanum Memorial Cancer Hospital and Research Center, Lahore, Pakistan, Lahore, PAK 2. Department of Surgical Oncology, Shaukat Khanum Memorial Cancer Hospital and Research Center, Lahore, PAK 3. Department of Surgical Oncology, Shaukat Khanum Memorial Cancer Hospital and Research Center, Lahore, Pakistan 4. Pathology, Shaukat Khanum Memorial Cancer Hospital and Research Center, Lahore, PAK 5. Biostatistician and Cancer Epidemiologist, Shaukat Khanum Memorial Cancer Hospital and Research Center, Lahore, PAK 6. Surgical Oncology, Shaukat Khanum Memorial Cancer Hospital and Research Center, Lahore, PAK 7. Department of Radiation Oncology, Shaukat Khanum Memorial Cancer Hospital and Research Center, Lahore, PAK

Corresponding author: Muhammad Faisal, muhammadfaisal5767@outlook.com

\section{Abstract \\ Background}

Salivary gland tumors are rare salivary gland malignancies with resemblance to ductal breast carcinoma. We have described clinicopathological behavior and treatment outcomes of this rare malignancy.

\section{Methods}

Salivary duct carcinoma patients treated from 2010 to 2015 were retrospectively analyzed for clinicopathological characteristics and treatment-related outcomes of the disease.

\section{Results}

A total of 12 patients with salivary duct carcinoma were included in the study. All were males with mean age of $52.58 \pm 13.43$. Parotid gland was the most commonly involved major salivary gland while buccal mucosa and anterior tongue were most common oral cavity sub-sites involving minor salivary glands. The diseasefree survival was $75 \%$ at 10 months and $25 \%$ at 20 months. The mean follow-up time was 12 months. There were three local recurrences and one distant metastasis.

\section{Conclusion}

Received 07/30/2018

Review began 08/05/2018 Review ended 08/10/2018 Published 08/14/2018

\section{(c) Copyright 2018}

Anwer et al. This is an open access article distributed under the terms of the Creative Commons Attribution License CC-BY 3.0., which permits unrestricted use, distribution, and reproduction in any medium, provided the original author and source are credited.
Salivary duct carcinoma is a locally aggressive tumor with tendency for local recurrence and distant metastasis. Adverse features such as perineural invasion, extra-capsular spread and advanced nodal disease may worsen prognosis.

Categories: Otolaryngology, Oncology, Other

Keywords: salivary duct carcinoma, salivary gland tumors, head and neck surgery

\section{Introduction}

Salivary duct carcinomas are rare tumors representing $10 \%$ of salivary gland malignancies. They may arise de novo or secondarily in a pre-existing pleomorphic adenoma. The histological features resemble to invasive ductal carcinoma of the breast and require immunohistochemistry to rule out metastasis among patients with previous history of breast carcinoma [1]. Salivary duct carcinomas have been classified as high-grade malignancies [2]. The standard treatment for salivary duct carcinoma of parotid gland is total parotidectomy, ipsilateral neck dissection followed by postoperative radiation therapy with or without concurrent chemotherapy; however, salivary duct carcinoma of parotid gland has grave dismal prognosis and chemotherapy may have a palliative role in metastatic disease [3].

Salivary duct carcinoma is a rare tumor, so limited studies have been published. We aim this study in describing clinicopathological behavior and treatment-related outcomes such as disease-free survival, patterns of failure and adverse pathological features affecting survival at a high volume tertiary care cancer center.

\section{Materials And Methods}


All patients' record was retrieved from the Cancer Registry Database of Shaukat Khanum Memorial Cancer Hospital. The patients with histological diagnosis of salivary duct carcinoma were selected from the database. Demographic records for each individual including age at diagnosis, gender, grade, stage, geographic location, treatment modality and follow-up were all retrospectively analyzed from the same database. All patients had a baseline computed tomography (CT) scan or magnetic resonance imaging (MRI) of the primary site. The study was exempted by the Institutional Review Board (IRB). Data were analyzed using IBM SPSS Statistics for Windows, Version 20.0 (released 2011, IBM Corp., Armonk, NY). Kaplan-Meier curves were used to analyze survival data.

\section{Results}

A total of 12 patients' records, diagnosed with salivary duct carcinoma of head and neck region from 2010 to 2015, treated at Shaukat Khanum Memorial Cancer Hospital, were retrospectively analyzed to describe the clinicopathological characteristics and treatment-related outcomes of the disease (Tables 1,2). All patients were males with the mean age of 52 years at presentation (Range 29-71). Primary site of involvement was parotid $(n=7)$, submandibular gland $(n=3)$, buccal mucosa $(n=1)$ and anterior tongue $(n=1)$. There was only one patient who was treated with palliative intent while remaining 11 underwent surgery followed by adjuvant treatment. Ipsilateral neck dissection was performed in five patients as nodal disease was evident on imaging studies. Majority of patients had R1 (microscopic residual disease) and R2 (macroscopic residual disease) resections $(n=8)$ with only two patients having clear resection surgical margins. There were four patients with positive perineural invasion and four with lympho-vascular involvement. Mean follow-up time was 12 months (Range 4-30). The Kaplan-Meier survival curve showed dismal results at 20 months after treatment (Figure 1). Mean dose for post-operative radiotherapy was 50.5 Grey given as daily 2 Grey/fraction five days/week over five weeks. 


\section{Cureus}

\begin{tabular}{|c|c|c|}
\hline Variables & Characteristics & Frequency $\mathrm{N}(\%)$ \\
\hline Age in years & Mean \pm SD* $^{*}$ & $52.58 \pm 13.43$ \\
\hline \multirow[t]{4}{*}{ Ethnicity } & Afghanistan & $2(16.7 \%)$ \\
\hline & Gilgit-Baltistan & $1(8.3 \%)$ \\
\hline & Khyber Pakhtunkhwa & $3(25.0 \%)$ \\
\hline & Punjab & $6(50.0 \%)$ \\
\hline \multirow[t]{2}{*}{ Site } & Oral cavity & 2 (16.7\%) \\
\hline & Salivary glands & $10(83.3 \%)$ \\
\hline \multirow[t]{4}{*}{ Subsite } & Buccal mucosa & $1(8.3 \%)$ \\
\hline & Parotid & $7(58.3 \%)$ \\
\hline & Submandibular & $3(25.0 \%)$ \\
\hline & Tongue anterior & $1(8.3 \%)$ \\
\hline \multirow[t]{5}{*}{ Clinical stage } & $\mathrm{X}$ & $1(8.3 \%)$ \\
\hline & 1 & $2(16.7 \%)$ \\
\hline & 2 & $1(8.3 \%)$ \\
\hline & 3 & $1(8.3 \%)$ \\
\hline & 4 & 7 (58.3\%) \\
\hline \multirow[t]{5}{*}{ Pathological stage } & $X$ & $2(16.7 \%)$ \\
\hline & 1 & $3(25.0 \%)$ \\
\hline & 2 & $3(25.0 \%)$ \\
\hline & 3 & $1(8.3 \%)$ \\
\hline & 4 & $3(25.0 \%)$ \\
\hline
\end{tabular}

TABLE 1: Clinical and demographic features.

"x" denotes disease which cannot be assessed. 


\section{Cureus}

\begin{tabular}{|c|c|c|c|c|c|c|c|c|}
\hline $\begin{array}{l}\text { Serial } \\
\text { No }\end{array}$ & $\begin{array}{l}\text { Age/ } \\
\text { Gender }\end{array}$ & Site & Treatment & Pathological stage & Adjuvant & Recurrence & $\begin{array}{l}\text { Follow up } \\
\text { (months) }\end{array}$ & Status \\
\hline 1 & $51 / \mathrm{M}$ & Parotid & RT & NA & & No & 10 & Alive \\
\hline 2 & $52 / \mathrm{M}$ & $\begin{array}{l}\text { Tongue } \\
\text { anterior }\end{array}$ & Surgery & $\begin{array}{l}\text { pT2N0 Re-excision No } \\
\text { PNI/LVI }\end{array}$ & NA & Regional & 13 & Alive \\
\hline 3 & 45/M & $\begin{array}{l}\text { Buccal } \\
\text { mucosa }\end{array}$ & Surgery & pT1N0 PNI+, Close Margin & RT & No & 10 & Alive \\
\hline 4 & 29/M & Parotid & Surgery & pT2N0 close margin & RT & No & 9 & Alive \\
\hline 5 & $64 / \mathrm{M}$ & Submandibular & Surgery & $\begin{array}{l}\text { pT3Nx PNI/LVI + Close } \\
\text { margin }\end{array}$ & RT & No & 4 & Died \\
\hline 6 & $66 / \mathrm{M}$ & Submandibular & $\begin{array}{l}\text { Surgery } \\
\text { outside }\end{array}$ & T4bN3 & RT & No & 6 & Died \\
\hline 7 & $66 / \mathrm{M}$ & Submandibular & Surgery & $\mathrm{T} 2 \mathrm{Nx}$ & NA & NA & 4 & $\begin{array}{l}\text { Lost to } \\
\text { Follow up }\end{array}$ \\
\hline 8 & $42 / \mathrm{M}$ & Parotid & Surgery & pT3NO & RT & Distant & 30 & Alive \\
\hline 9 & $63 / M$ & Parotid & Surgery & $\begin{array}{l}\text { pT4aN3b PNI + ECS+ } \\
\text { Close margin }\end{array}$ & RT & $\begin{array}{l}\text { Local (Intracranial } \\
\text { Extension) }\end{array}$ & 30 & Alive \\
\hline 10 & $36 / \mathrm{M}$ & Parotid & Surgery & $\begin{array}{l}\text { pT3N3 PNI/LVI + ECS+ } \\
\text { Close margin }\end{array}$ & RT & Local & 22 & Alive \\
\hline 11 & 46/M & Parotid & Surgery & $\begin{array}{l}\text { pT1Nx PNI+, Involved } \\
\text { margin }\end{array}$ & RT & No & 20 & Alive \\
\hline 12 & $71 / \mathrm{M}$ & Parotid & Surgery & pT1Nx & RT & No & 5 & Alive \\
\hline
\end{tabular}

\section{TABLE 2: Clinicopathological characteristics.}

RT: Radiotherapy; PNI: Perineural Invasion; LVI: Lymphovascular Invasion; ECS: Extracapsular Spread; M: Male; p: Pathological; NA: Not Applicable.

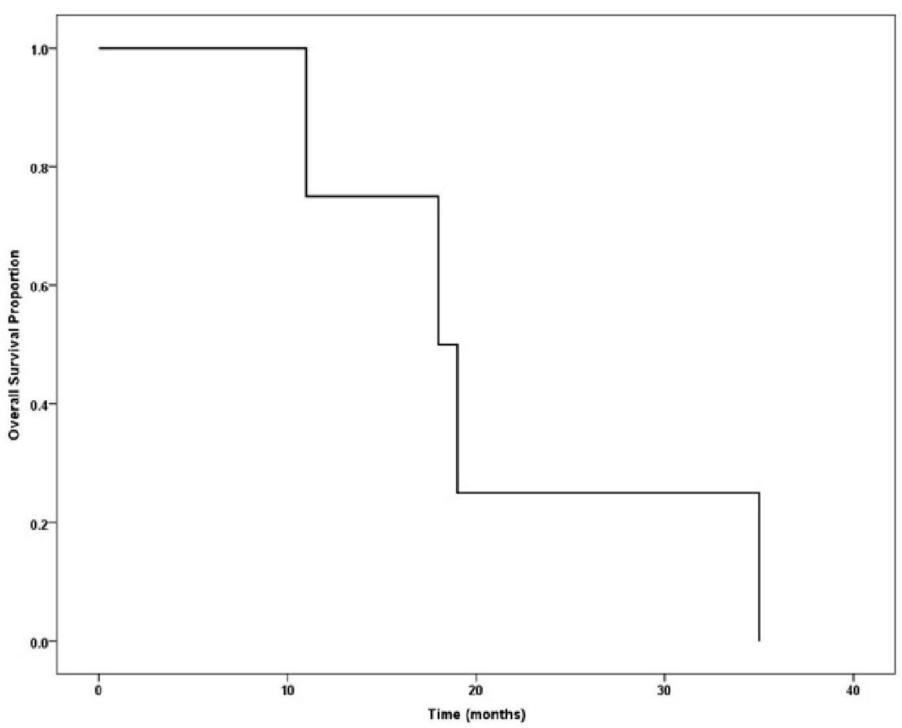

FIGURE 1: Disease-free survival (DFS) in months.

\section{Discussion}

Kleinsasser et al. have used the term 'salivary duct carcinoma' due to its resemblance to ductal carcinomas of the breast. Reported case series have re-classified many of these tumors into epithelial-myoepithelial and 


\section{Cureus}

polymorphous low-grade adenocarcinoma resulting in difficulty of establishing the actual incidence [4]. The majority of case series and reports have shown aggressive nature of the disease, propensity for nodal metastasis and strong tendency for loco-regional recurrence and distant metastasis. The close resemblance to ductal carcinoma of the breast is attributed to comedo-type necrosis and calcifications microscopically and cystic changes macroscopically [5] as shown in Figures 2, 3. The poor prognosis and aggressive nature of these tumors have suggested that accurate diagnosis so that timely intervention may improve outcomes. Cytological literature comprises more of case reports and small case series [6,7]. Cribriform, trabecular, acinar and papillary formations can be seen (Figure 4). The individual cells are large, monomorphic to pleomorphic, and polygonal to cuboidal, with abundant, finely granular cytoplasm (Figure 5). Squamoid and oncocyte-like appearances are also seen [8]. Due to similar nature of salivary duct carcinoma and breast ductal carcinoma, over-expression of androgen receptor, human epidermal growth factor receptor 2 (HER2)/neu proto-oncogene has also been studied (Figure 6). The reported rate is around $20-25 \%$ and this trend is similar to our case series where two of our patients were human epidermal growth factor receptor (HER-2) positive while one was androgen receptor positive (Figure 5) [9,10]. The differential diagnosis for high-grade salivary duct carcinoma includes the papillary cystic and microcystic variants of acinic cell carcinoma, metastatic squamous cell carcinoma, metastatic breast cancer, melanoma, mucoepidermoid carcinoma, and oncocytic carcinoma. Based on nuclear findings, it may be possible to distinguish salivary duct carcinoma from other high-grade salivary gland carcinomas, by immunostaining for androgen receptor, gross cystic disease fluid protein-15 and p63 [11,12].

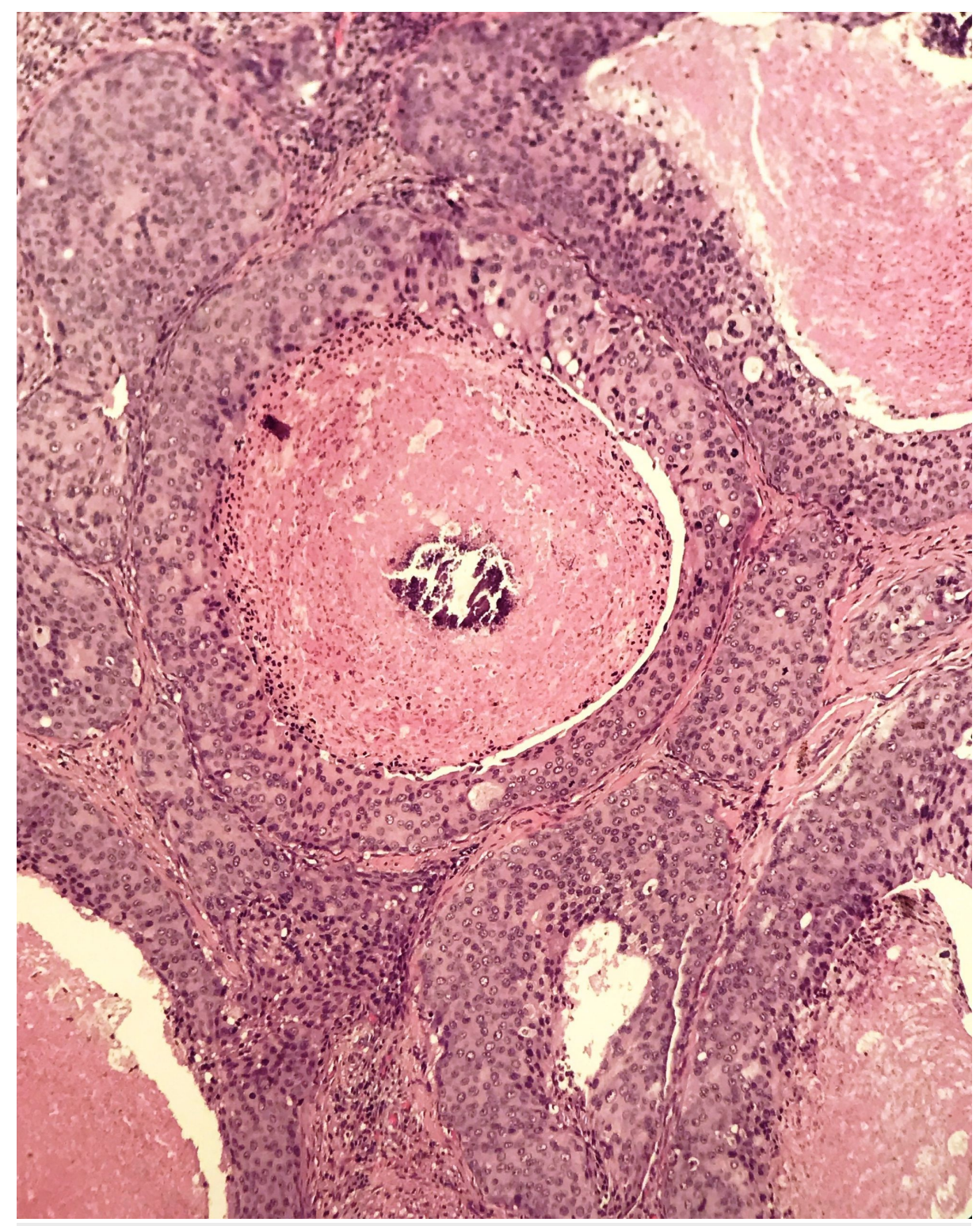

FIGURE 2: Lobules displaying central comedo-like necrosis and microcalcifications, similar to the ductal carcinoma in situ (DCIS) of the breast. (H\&E, 20x Magnification) 


\section{Cureus}

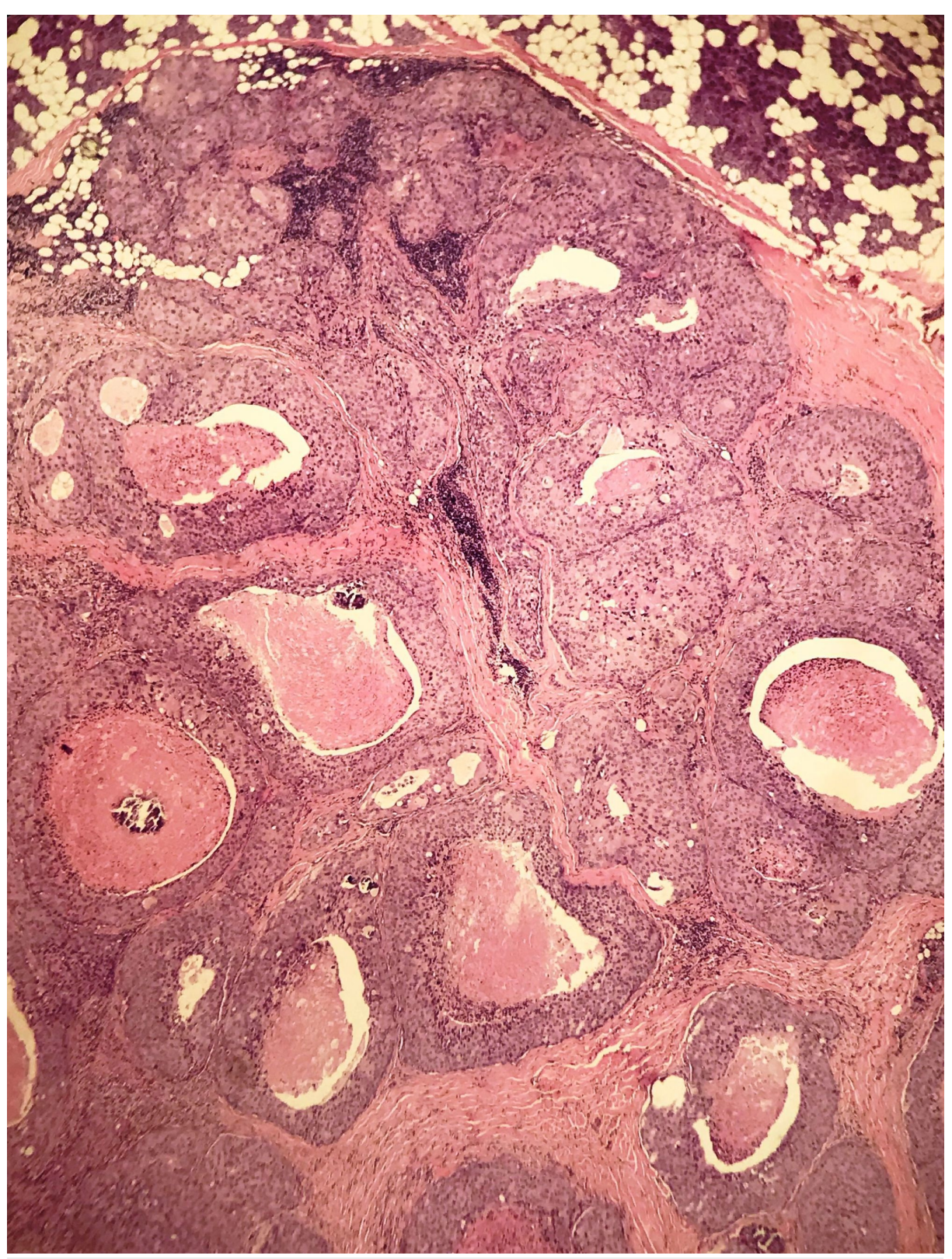

FIGURE 3: Salivary duct carcinoma, displaying prominent eosinophilic appearance, rounded and variably sized solid and cystic lobules. (H\&E, 10x Magnification) 


\section{Cureus}

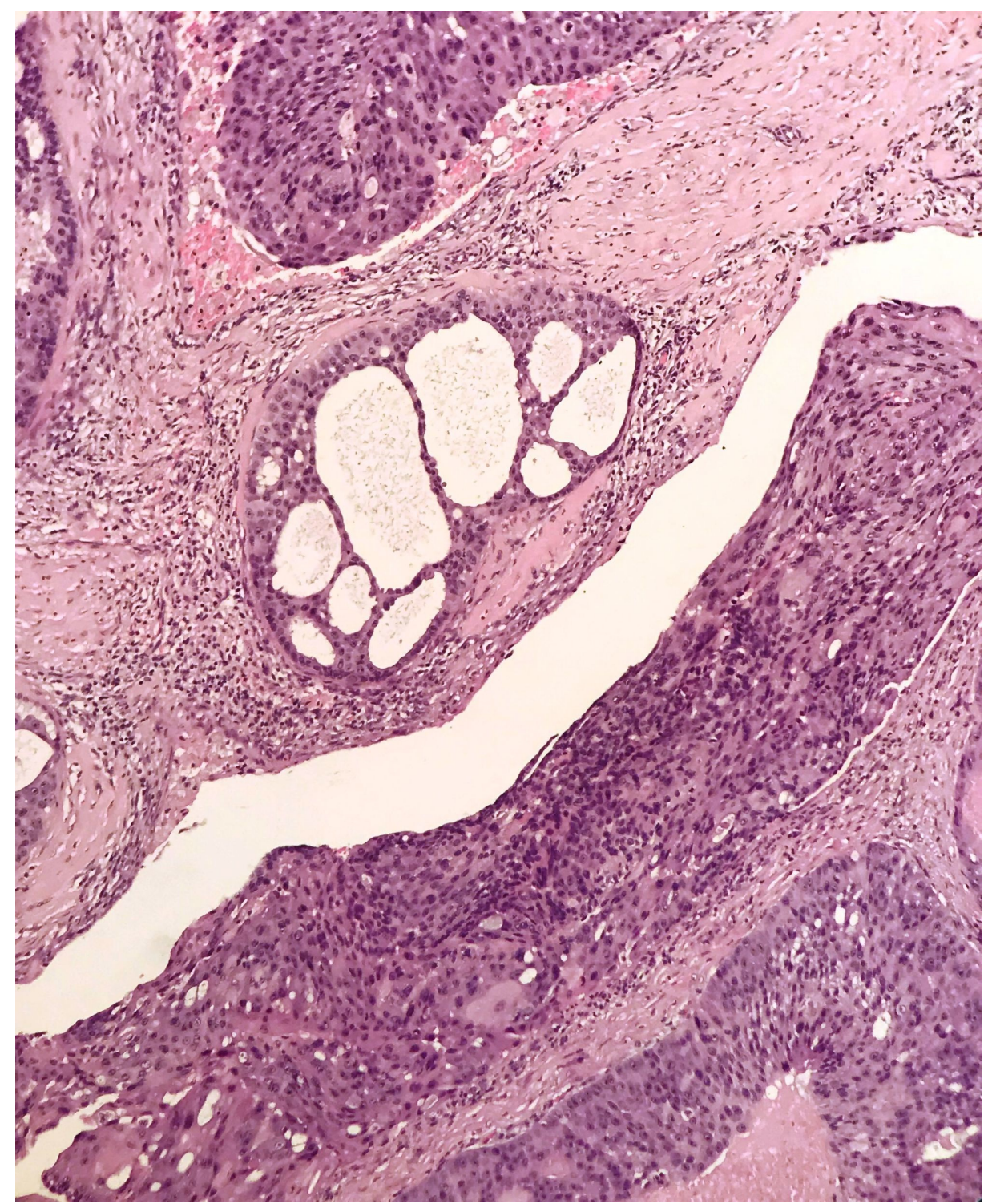

FIGURE 4: A focus showing cribriform nest (H\&E,10x Magnification) 


\section{Cureus}

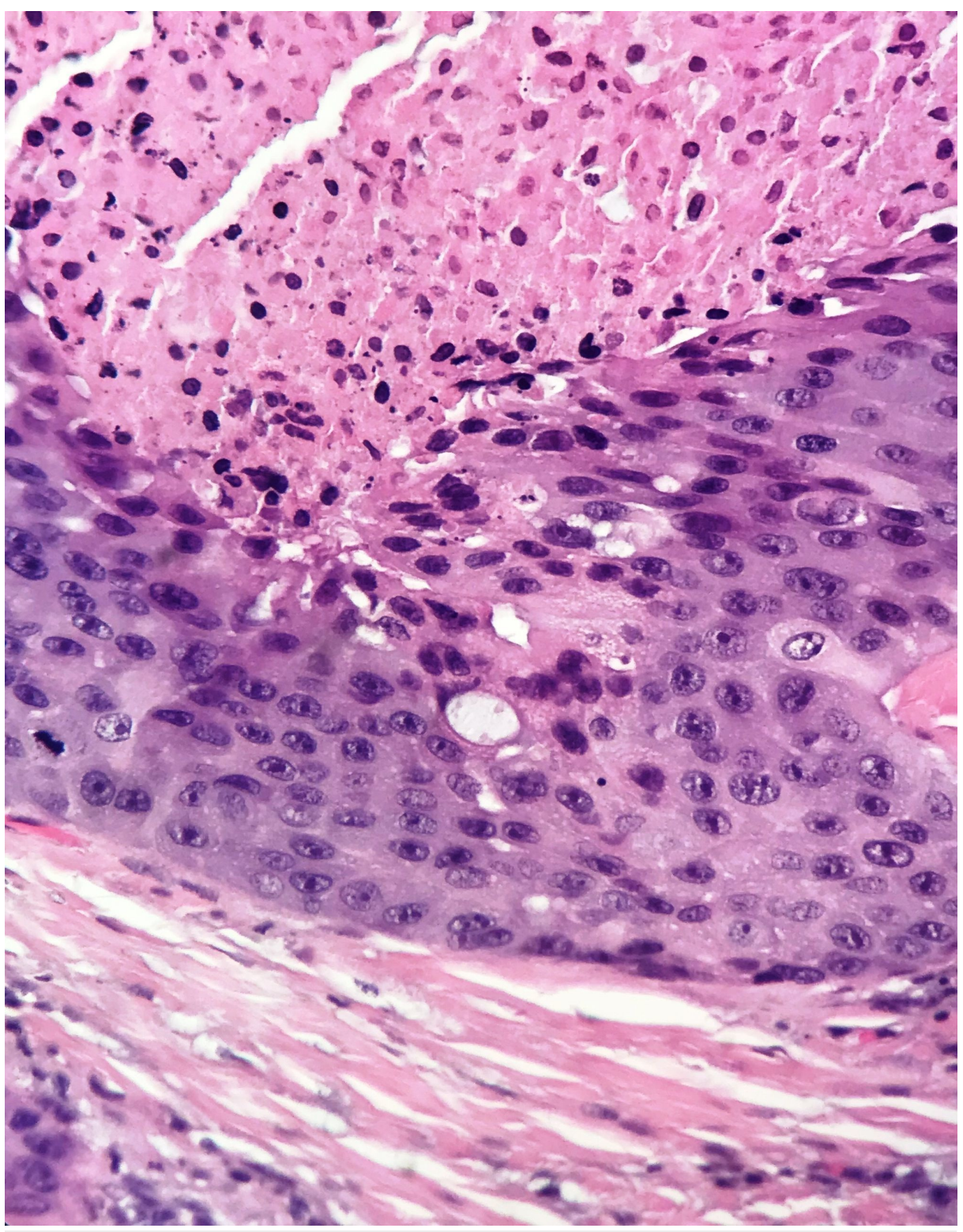

FIGURE 5: Tumor cells showing abundant eosinophilic cytoplasm, hyperchromatic nuclei with visible nucleoli. (H\&E, 40x Magnification) 


\section{Cureus}

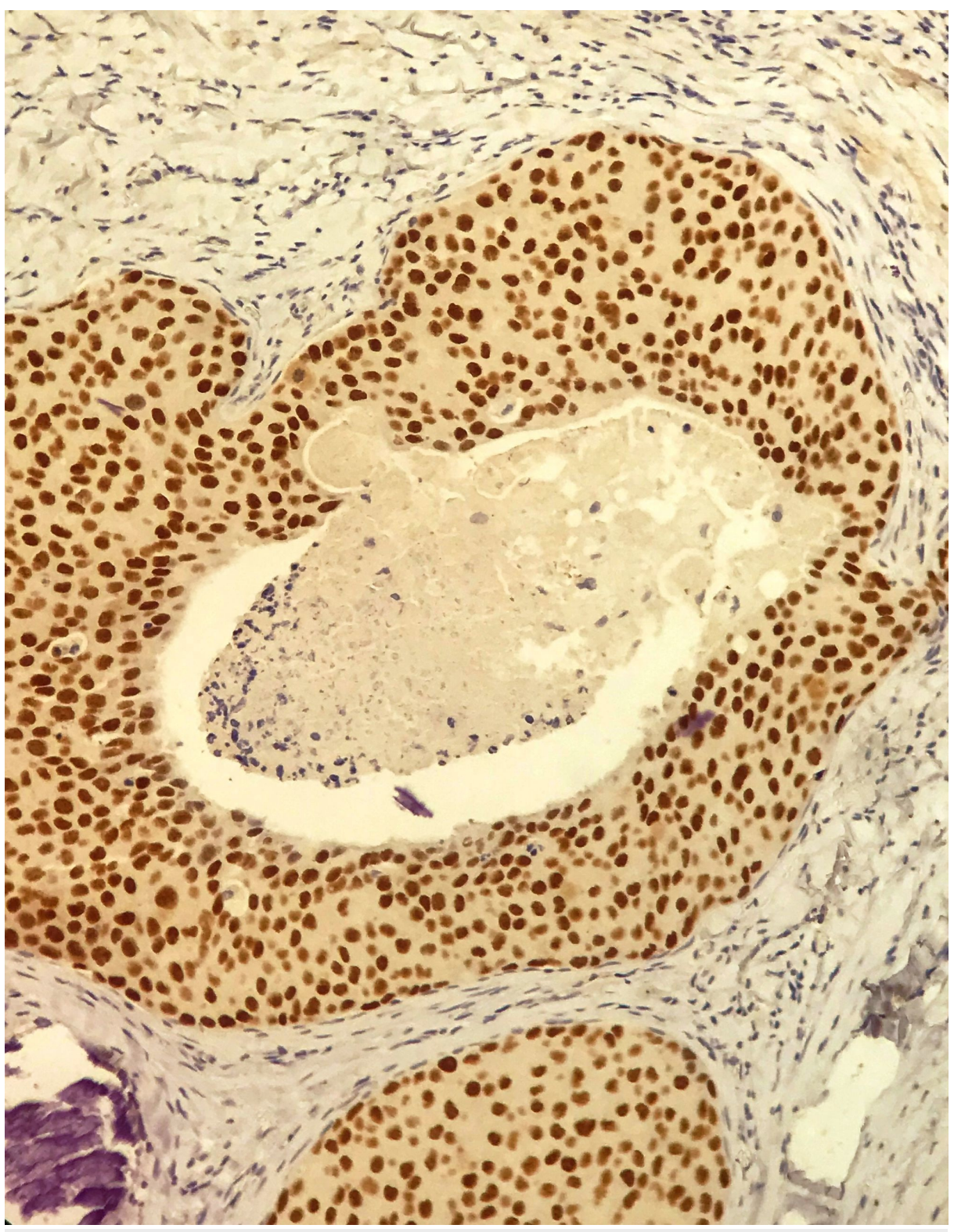

\footnotetext{
FIGURE 6: Nuclear positivity of androgen receptor (AR) among the tumor cells.
}

Parotid gland is the more commonly involved site (88\%) in literature followed by submandibular gland (8\%). Men are three times more likely to get salivary duct carcinoma than women $[13,14]$. Rarely, there is involvement of minor salivary glands and larynx [15-17]. Among salivary glands, parotid gland involvement was found to be in majority (70\%) of cases followed by submandibular gland (30\%). Most commonly involved oral cavity sub-sites were buccal mucosa and anterior tongue.

Due to high incidence of loco-regional recurrence and distant metastasis resulting in dismal survival outcome, aggressive approach should be the mainstay of treatment. Local failure was observed in three of our patients while one developed distant metastasis. Delgado et al. have suggested preserving facial nerve if not involved while Colmenero Ruiz et al. have advocated sacrificing the nerve even in superficial tumors $[18,19]$. The reported incidence of neck metastasis is $65 \%$ thus elective neck management should be recommended. Other adverse features such as perineural/ympho-vascular invasion may have a role in local recurrence other than close or positive margin. Only $25 \%$ of our patients developed local recurrence and both were positive for perineural invasion and extra-nodal extension. Only $20 \%$ of patients had clear surgical margins while $40 \%$ had close and $40 \%$ had involved margins. None of the patients with involved margins developed local recurrence. Adjuvant radiotherapy has shown to be effective in terms of survival outcome in literature but small number of patients in reported series and retrospective studies have raised a concern whether or not it should be a part of treatment guidelines [13]. Adjuvant radiotherapy was given to nine of our patients and only two have developed local recurrence while one had distant failure. In breast cancer, 
detection of human epidermal growth receptor 2 (HER-2) gene amplification increases the identification of responders to targeted therapy [20-22]. Metastatic salivary duct carcinomas have shown good response to trastuzumab [23-25]. This may open up further avenues in determining the role of adjuvant chemotherapy for immunohistochemical marker positive tumors. Previous studies have shown that advanced nodal disease, lymphovascular invasion and extra-capsular spread have negative impact on survival [26]. Estimated disease-free survival in our series stayed at $75 \%$ at 10 months but control rates were poor (25\%) at 20 months. The cases with local recurrence were both positive for perineural invasion, extras-capsular spread and having an advanced nodal disease. The limitations of this study are retrospective nature, small sample size and short follow-up.

\section{Conclusions}

Salivary duct carcinoma is among the high grade aggressive salivary gland tumors resembling ductal carcinoma of the breast. Early recurrence and strong tendency for local and distant metastasis have worse impact on survival. Surgery followed by radiotherapy to both primary and cervical bed seems to be the preferred treatment. Due to increased likelihood of cervical metastasis, elective neck management should be performed in these tumors.

\section{Additional Information \\ Disclosures}

Human subjects: Consent was obtained by all participants in this study. Shaukat Khanum Memorial Cancer Hospital and Research Center Review Board issued approval NA. The authors declare that they have no conflict of interest. Patient's related information has not been included in the article. Animal subjects: All authors have confirmed that this study did not involve animal subjects or tissue. Conflicts of interest: In compliance with the ICMJE uniform disclosure form, all authors declare the following: Payment/services info: All authors have declared that no financial support was received from any organization for the submitted work. Financial relationships: All authors have declared that they have no financial relationships at present or within the previous three years with any organizations that might have an interest in the submitted work. Other relationships: All authors have declared that there are no other relationships or activities that could appear to have influenced the submitted work.

\section{Acknowledgements}

Thanks to Dr. Arif Jamshed and Dr. Raza Hussain for all the support and guidance.

\section{References}

1. McHugh JB, Visscher DW, Barnes EL: Update on selected salivary gland neoplasms. Arch Pathol Lab Med. 2009, 133:1763-1774.

2. Huang X, Hao J, Chen S, Deng R: Salivary duct carcinoma: a clinopathologic report of 11 cases . Oncol Lett. 2015, 10:337-341. 10.3892/ol.2015.3176

3. Nabili V, Tan JW, Bhuta S, Sercarz JA, Head CS: Salivary duct carcinoma: a clinical and histologic review with implications for trastuzumab therapy. Head Neck. 2007, 29:907-912. 10.1002/hed.20614

4. Kleinsasser O, Klein HJ, Hubner G: Salivary duct carcinoma: a group of salivary gland tumours analogous to mammary duct carcinoma (Article in German). Arch Klin Exp Ohren Nasen Kehlkopfheilkd. 1968, 192:100105.

5. Lewis JE, McKinney BC, Weiland LH, Ferreiro JA, Olsen KD: Salivary duct carcinoma: clinicopathologic and immunochemical review of 26 cases. Cancer. 1996, 77:223-230. 10.1002/(SICI)10970142(19960115) 77:2<223::AID-CNCR1>3.0.CO;2-N

6. Khurana KK, Pitman MB, Powers CN, Korourian S, Bardales RH, Stanley MW: Diagnostic pitfalls of aspiration cytology of salivary duct carcinoma. Cancer. 1997, 81:373-378. 10.1002/(SICI)10970142(19971225)81:6<373::AID-CNCR12>3.0.CO;2-W

7. Garcia-Bonafe M, Catala I, Tarragona J, Tallada N: Cytologic diagnosis of salivary duct carcinoma: a review of seven cases. Diagn Cytopathol. 1998, 19:120-123. 10.1002/(SICI)1097-0339(199808)19:2<120::AIDDC11>3.0.CO;2-H

8. Gilcrease MZ, Guzman-Paz M, Froberg K, Pambuccian S: Salivary duct carcinoma: is a specific diagnosis possible by fine needle aspiration cytology?. Acta Cytologica. 1998, 42:1389-1396. 10.1159/000332173

9. Jaehne M, Roeser L, Jaekel T, Schepers JD, Albert N, Löning T: Clinical and immunohistologic typing of salivary duct carcinoma: a report of 50 cases. Cancer. 2005, 103:2526-2533. 10.1002/cncr.21116

10. Padberg BC, Sasse B, Huber A, Pfaltz M: Sarcomatoid salivary duct carcinoma. Ann Diagn Pathol. 2005, 9:86-92. 10.1016/j.anndiagpath.2004.12.005

11. Kawahara A, Harada H, Akiba J, Kage M: Salivary duct carcinoma cytologically diagnosed distinctly from salivary gland carcinomas with squamous differentiation. Diagn Cytopathol. 2008, 36:485-493. 10.1002/dc. 20823

12. Moriki T, Ueta S, Takahashi T, Mitani M, Ichien M: Salivary duct carcinoma: cytologic characteristics and application of androgen receptor immunostaining for diagnosis. Cancer. 2001, 93:344-350.

13. Hosal AS, Fan C, Barnes L, Myers EN: Salivary duct carcinoma. Otolaryngol Head Neck Surg. 2003, 129:720725 .

14. Sartorius C, Gille F, Bédrossian-Pfingsten J, Kemp HG: Salivary duct carcinoma of the sublingual gland - a case report (Article in German). Laryngo-Rhino-Otol. 2006, 85:517-519. 10.1055/s-2005-921217 
15. Huh KH, Heo MS, Lee SS, Choi SC: Three new cases of salivary duct carcinoma in the palate: a radiological diagnosis and review of the literature. Oral Surg Oral Med Oral Pathol Oral Radiol Endod. 2003, 95:752-760. 10.1067/moe.2003.246

16. Jeong HS, Son YI, Ko YH, Kim SY: Sarcomatoid salivary duct carcinoma of the larynx . J Laryngol Otol. 2006, 120:154-157. 10.1017/S0022215105003518

17. Goel MM, Agrawal SP, Srivastava AN: Salivary duct carcinoma of the larynx: report of a rare case . Ear Nose Throat J. 2003, 82:371-373.

18. Delgado R, Vuitch F, Albores-Saavedra J: Salivary duct carcinoma. Cancer. 1993, 72:1503-1512.

19. Colmenero Ruiz C, Patron Romero M, Martin Perez M: Salivary duct carcinoma: a report of nine cases . J Oral Maxillofac Surg. 1993, 51:641-646. 10.1016/S0278-2391(10)80263-0

20. Simpson RHW, Desai S, Di Palma S: Salivary duct carcinoma in situ of the parotid gland . Histopathology. 2008, 53:416-425. 10.1111/j.1365-2559.2008.03135.x

21. Wolff AC, Hammond ME, Schwartz JN, et al.: American Society of Clinical Oncology/College of American Pathologists guideline recommendations for human epidermal growth factor receptor 2 testing in breast cancer. J Clin Oncol. 2006, 25:118-145. 10.1200/JCO.2006.09.2775

22. Ligibel JA, Winer EP: Trastuzumab/chemotherapy combinations in metastatic breast cancer. Semin Oncol. 2002, 29:38-43. 10.1016/S0093-7754(02)70125-5

23. Prat A, Paraera M, Reyes V, et al.: Successful treatment of pulmonary metastatic salivary ductal carcinoma with trastuzmab-based therapy. Head Neck. 2008, 30:680-683. 10.1002/hed.20714

24. Glisson B, Colevas AD, Haddad R, et al.: HER 2 expression in salivary gland carcinomas: dependence on histologic subtype. Clin Cancer Res. 2004, 10:944-946. 10.1158/1078-0432.CCR-03-0253

25. Nabili V, Tan JW, Bhuta S, Sercarz JA, Head CS: Salivary duct carcinoma: a clinical and histologic review with implications for trastuzumab therapy. Head Neck. 2007, 29:907-912. 10.1002/hed.20614

26. Johnston ML, Huang SH, Waldron JN, et al.: Salivary duct carcinoma: treatment, outcomes, and patterns of failure. Head Neck. 2016, 38:820-826. 10.1002/hed.24107 